\title{
Application of the Entropy Theory \\ for Electric Connection Schemes Reliability Analisys of Traction Substations
}

\author{
Vladislav G. Belov, \\ Alexey V. Bobrov and Vladimir A. Tremyasov* \\ Siberian Federal University \\ 79 Svobodny, Krasnoyarsk, 660041, Russia
}

Received 21.12.2018, received in revised form 18.01.2019, accepted 21.02.2019

Entropy criteria of traction substations of 110-220 kV schemes' unreliability are considered in this article in the conditions of indeterminacy of schemes' conditions. It is shown how the application of entropy estimates during scheduling reconstruction of traction substations allows to estimate effectiveness of measuring to increase non-failure operation and substations' schemes electrical connections availability.

Keywords: traction substation, reliability, entropy estimates.

Citation: Belov V.G., Bobrov A.V., Tremyasov V.A. Application of the entropy theory for electric connection schemes reliability analisys of traction substations, J. Sib. Fed. Univ. Eng. technol., 2019, 12(3), 314-322. DOI: 10.17516/1999-494X-0138.

\section{Применение теории энтропии}

\section{для анализа надежности схем}

\section{электрических соединений тяговых подстанций}

\author{
В.Г. Белов, А.В. Бобров, В.А. Тремясов \\ Сибирский федеральный университет \\ Россия, 660041, Красноярск, пр. Свободньій, 79
}

В статье рассматриваются энтропийные критерии ненадежности схем тяговых подстанций 110-220 кB в условиях неопределенности состояний схем. Показано, что применение энтропийных оценок при планировании реконструкции тяговых подстанций позволяет оценить эффективность мер по повышению безотказности и готовности схем электрических соединений подстанциий.

Ключевые слова: тяговая подстанция, надежность, энтропийные оценки.

(C) Siberian Federal University. All rights reserved

This work is licensed under a Creative Commons Attribution-NonCommercial 4.0 International License (CC BY-NC 4.0).

* Corresponding author E-mail address: belov_v2012@mail.ru 


\section{Introduction}

The main consumer of the electric power on railway transport is the alternating current electric train (ACET). Therefore, the functions of the traction substation (TS) are transformation of the electric power from one voltage level to another and power distribution through contact network by means of a feed line, with its subsequent transfer on the ACET current collector. Besides this ACET, traction substations implement the electric power supply of railway stations, locomotive and carriage depots, communication devices and automatic lock-outs, adjacent houses and the industrial enterprises. The violation of power supply and distribution, in turn, involves violation of the schedule and idle time of trains, shutdowns of the adjacent enterprises operation and the electric power supply of non-traction consumers, etc [1].

The comparative analysis and abilities assessment of the existing methods shows the necessity to develop the method of TS's functioning reliability and effectiveness analysis as a complex technical system with a large number of states, basing on traditional methods, considering on features of construction and functioning of this system.

The purpose of the issue is the development of the method based on entropy assessment and its application reliability assessment of electrical connections traction substations of $110-220 \mathrm{kV}$ schemes.

The following tasks are solved in the present article:

- the research of entropy estimates using possibility for the analysis of TP reliability;

- the calculation of entropy indicators of reliability for various TP $110-220 \mathrm{kV}$ schemes;

- scheduling the reconstruction of TP $110-220 \mathrm{kV}$ schemes.

\section{Application of an entropy theory for the electric installations reliability analysis}

The sets variety degree of any elements (events, states) depends on total number of the elements entering this set and their specific gravity in this set. Specific weights of various elements usually are defined by the probability to receive an element of this type at random sampling of this set.

There is the entropy of this set $A$ elements determined by expression [2] serves in cybernetics for the variety measurement of a set:

$$
H(A)=-\sum_{i=1}^{n} p_{i} \log _{2} p_{i}
$$

where $H(A)$ - the entropy of the set $A ; p_{\mathrm{i}}$ - emergence probability of an element $i$ at random sampling of a set of A. Toting is made with all elements of the complete set of elements $\sum_{i=1}^{n} p_{i}=1$.

The entropy defined on (1) has the following properties:

- the entropy reaches in zero when emergence of one element of a set is reliable, and others is impossible;

- at the given number of various elements the entropy has a maximum when emergence of these elements has the same probability;

- the entropy increases at increasing in number of elements in a set; 
- the entropy has property of additivity: when sets of independent elements (events) unite in one, their entropy is summarized, and the sum is an entropy of the integrated set.

The entropy can be used as reliability assessment of a system by definition of indeterminacy measuring of system conditions in the quantitative look through its probabilistic characteristics [3].

Entropies for the difficult sets (for the difficult sets of their entropy) are calculated by means of tables of a higher transcendental function $\eta(p)=-p \log _{2} p$.

Under union of two sets $A$ and $B$ with possible elements, $a_{1}, \ldots, a_{n}$ and $b_{1}, \ldots, b_{m}$ is understood a set $(A, B)$ which elements represent all possible combinations of the $a_{i}$ and $b_{j}$ elements which number is equal to $n \cdot m$.

Designating through $p_{i j}$ the emergence probability of the $a_{i} b_{j}$ element in a set $(A, B)$.

The definition (1) represents an entropy of a set $(A, B)$ :

$$
H(A, B)=-\sum_{i=1}^{n} \sum_{j=1}^{m} p_{i j} \log _{2} p_{i j}
$$

The united entropy is equal to the sum of items' entropies at uniting of independent events sets (elements, actions):

$$
H(A, B)=H(A)+H(B) .
$$

We receive the equation in case of uniting dependent sets:

$$
H(A, B)=H(A)+H(B / A)=H(B)+H(A / B),
$$

here are $H(A / B), H(B / A)$ - average conditional entropies of sets $A$ and $B$.

The conditional entropy of a set of $B$ provided that in a set of $A$ the $a_{i}$, element appeared, is called the value determined by the equation:

$$
H\left(B / \alpha_{i}\right)=\sum_{j=1}^{m} \eta\left[P\left(b_{j} / a_{i}\right)\right]
$$

where $P\left(b_{j} / a_{i}\right)$ - the conditional probability of emergence of the $b_{j}$ element a set of $B$ if in a set $A$ the $a_{i}$ element appeared.

The average conditional entropy $H(B / A)$ is defined as an expectation of the conditional entropy:

or

$$
H(B / A)=\sum_{i=1}^{n} p_{i} H\left(B / a_{i}\right)
$$

$$
H(B / A)=\sum_{i=1}^{n} \sum_{j=1}^{m} p_{i} \eta\left(b_{j} / a_{i}\right)
$$

The inequality is called the main inequality of Shannon:

$$
H(B / A) \leq H(B) .
$$

From (5) and (3) follows that $H(A, B) \leq H(A)+H(B), H(A, B, C) \leq H(A)+H(B)+H(C)$.

Thus, the entropy is a measure of the elements variety of any sets. If these elements are casual events or conditions of any physical or technical system, then the entropy is a measure of indeterminacy 
of a condition of this system. As shown in [4], the entropy can become also a measure of unreliability of a system under some conditions.

If the task of all system entropy determination in general is set, the information measuring for a set of elements $n$ (everyone from which has two states) can be determined by expression:

$$
H=-\sum_{i=1}^{n}\left(p_{i} \log _{2} p_{i}+q_{i} \log _{2} q_{i}\right)
$$

where $p_{i}$ - the probability of non-failure operation; $q_{i}$ - the probability of $i$-element failure of the system.

Expression (6) reflects existence of the general measure of information or the generalized entropy.

Statistical data on behavior of a system are necessary to be used in this formula: the number of failures and restitutions, a response time in operating condition, in the condition of failure, etc.

Any power supply system or traction substation which is exposed various accidents and devices of relay protection and false drops of automatic relaying protection equipment (ARPE) can be presented by the following scheme (Fig. 1). $D$ is a set of potential damages and accidents; $L$ is a system of couplings and conditions in electric installation (EI); $E$ is a set of conditions of EI; $R$ is a set of possible actions of ARPE.

According to [5] the following condition is satisfied for the specified sets:

$$
H(E) \geq H(D)+H(R / D)-H(R),
$$

where $H(E)$ - the entropy of the conditions set of EI; $H(R), H(D)$ - the entropies of sets of R and $D$; $H(R / D)$ - the average conditional entropy of sets of $\mathrm{R}$ at the influence determined by the managing director from a great number of $D$.

Inequality (7) is a formula of a law of requisite variety [5]. According to (7) entropy of conditions of $H(E)$ has a minimum, and this minimum will be the least if $R$ is the single-valued function from $D$, i.e. ARPE has fault-free operation:

$$
H(E)=H(D)-H(R) \text { when } H(R / D)=0 .
$$

It is possible to claim that the minimum value of an entropy of states $H(E)$ can be reduced concerning an entropy of indignations of $H(D)$ only due to the same increase in an entropy of actions of ARPE. The entropy of a set of conditions of EI $H(E)$ is defined both its normal operational, and the critical conditions and is a measure of indeterminacy of conditions of EI. Therefore, (8) is the expres-

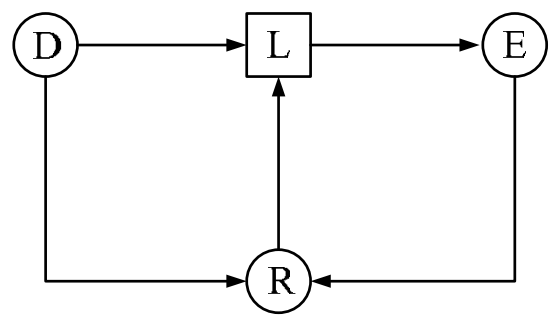

Fig. 1. Relations between sets of D, E and R 
sion for minimum unreliability which can be provided at the given set of accidents $D$ and a set of the chosen influences $R$ ARPE on condition of their non-failure operation.

The expression (7) allows to estimate a minimum of unreliability of the automated and operated EI taking into account a set of damages, a variety of the revolting influences of a variety of actions and reliability of its ARPE, because the entropy of $H(R / D)$ is a measure of unreliability of actions of ARPE. Probabilities of element's emergences of a set $E$ can be connected with probabilities of EI elements finding in various states: normal (admissible) $p_{i}$ and the emergency $q_{i}$. Then the entropy will be readiness measurement, measuring the indeterminacy to find EI in operational or non-operational state of its elements.

As the availability quotients of electric equipment are close to 1 , the value of $H_{q}(E)$ is close to zero and its application is limited. Having determined probabilities of $P$ and $Q$ for all EI, it is possible to consider $H_{q}\left(E_{a}\right)$ as an uninterrupted operation measure.

The probabilities of elements' appearance in set $E$ can connected with probabilities of the failure events leading to non-operational conditions of $Q(t)$, and non-failure operation of $P(t)$ during the given time of $t$. In this case the entropy $H_{Q}(E)$ will be non-failure operation measurement, measuring the indeterminacy to get non-failure operation or any EI's failures.

The entropy $H_{Q}(E)$ is the function of time. $H_{Q}(E)$ is close to zero due to high probability of nonfailure operation by consideration of an infinitesimal interval of time. $H_{Q}(E)$ grows increasing the considered interval of time due to increasing in probabilities of failures and accidents and its maximum comes with a frequency of failures close to 1 .

If in EI there are not any element's failures leads to failure of all installation or to accident, then having connected entropy size only with two probabilities of $P_{\mathrm{a}}$ and $Q_{\mathrm{a}}=1-P_{\mathrm{a}}$, where $P_{\mathrm{a}}-$ the probability of fault-free operation, and $Q_{\mathrm{a}}$ - the probability of failure emergence, we will receive a failsafety measure $H_{Q}\left(E_{a}\right)$.

The probability of elements emergence of a set $D$ can be connected with probabilities $Q(t)$ of various elements failures in installation or probability of lack of any failures $P(t)$.

The entropy of $H_{Q}(D)$ will be defined as an entropy or an indeterminacy measurement of damages and failures, and the entropy of indignations [6].

Entropies of readiness and uninterrupted operation of one element $H_{q}\left(E_{a}\right)=H_{q}(E)$ and

$$
H_{q}(E)=\eta(r)+\eta(q),
$$

where $p$ is availability quotient; $q$-idle time coefficient, here $p+q=1$.

The equation (10) is in case of one element for assessment of an entropy of non-failure operation $H_{Q}(E)$ and fail-safety of $H_{Q}\left(E_{a}\right)$

$$
H_{Q}(E)=\eta(P)+\eta(Q)
$$

where $P(t)+Q(t)=1, P(t)$ - the probability of non-failure operaion during $t$ time; $Q(t)$ - failure probability during $t$ time.

In case of a Poisson stream of failures:

$$
P(t)=e^{-a},
$$

where $a$ - the average number of failures during $t$ time; in case of the simplest stream $a=\lambda t$. 
There are various methods of assessment of reliability of power supply systems. However many of them were developed for a research of reliability of electric installations at design stages [4]. The analysis of the existing methods shows that assessment of system's reliability of traction power supply under operating conditions and also in the course of reconstruction is expedient to use entropy criteria when scheduling versions of schemes of traction power supply.

Example. Schemes of systems of traction power supply of 110-220 kV are provided on Fig. 2.

The first scheme (Fig. 2a) is more prime and cheap. An alternative for this scheme is the scheme with application of more expensive, but also more reliable gas-insulated switches (Fig. 2b) instead of cheap one, but less reliable devices OD-KZ [7].

The scheme "Two Blocks with OD-KZ, and a Non-automatic Crossing Point from Lines" is forbidden by the modern norms of technological projection of PS [8] to application. However, it often meets on traction substations, and still is on stream for a delivery of contact network of the railroads. It is necessary to use alternating-current vacuum switches with the spring drive without oil isolation according to the requirements established by the owner of infrastructure [9], both on again constructed, and on the reconstructed linear devices of traction power supply.

Indicators of reliability of settlement elements of schemes are given in Table 1.

Estimating effectiveness of these actions by means of entropy indicators [4, 10]:

- $H_{Q}\left(E_{a}\right)$ is an entropy of fail-safety;

- $H_{Q}(D)$ is an entropy of indignations;

- $H_{Q}(R)$ is an entropy of actions of ARPE and a control system.

It is necessary to estimate those values to calculate presented indicators:

$a$ - median number of repayments of consumers;

$T_{t . a v}$ - average time of restitution of a delivery;

$q_{i t}-$ the value of coefficient of idle time.

For TS schemes (Fig. 2), calculated by a table and logical technique [4] at $t_{p}=1$ year, the value of the specified indexes are provided in Table 2.

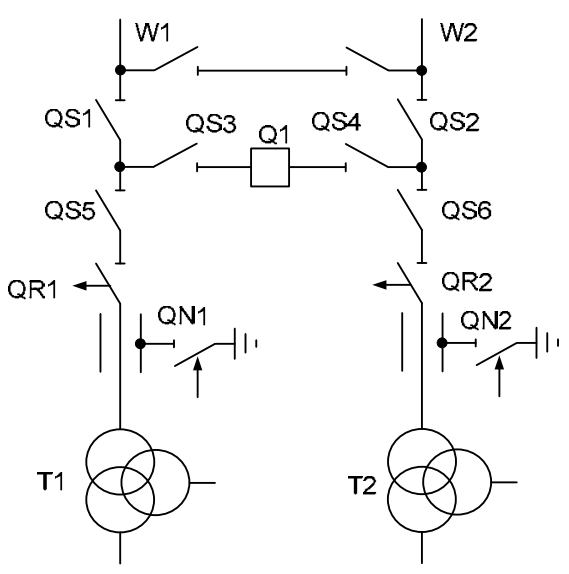

a)

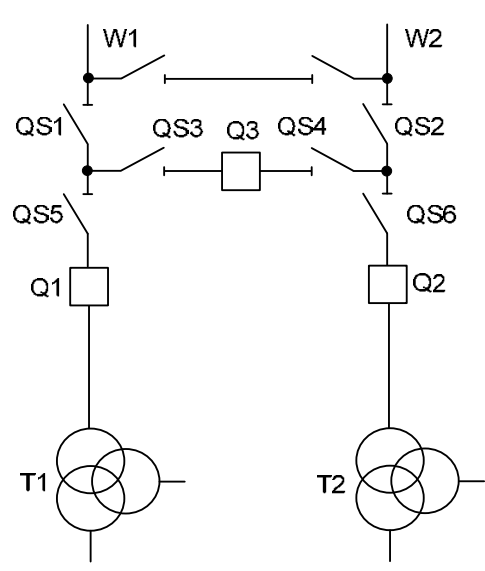

b)

Fig. 2. a) scheme "Two Blocks with Separators and a Non-automatic Crossing Point from Lines"; b) scheme "Two Blocks with Switches and a Non-automatic Crossing Point from Lines" 
Table 1. Indexes of reliability of the capital equipment of $110 \mathrm{kV}$ [7].

\begin{tabular}{|l|c|c|c|}
\hline \multicolumn{1}{|c|}{ Equipment } & $\lambda, 1 /$ year & $T_{r}$, hours & $T_{p l}$, hours/year \\
\hline The transformer, damage with short circuit (s.c.) & 0,014 & 70 & 28 \\
\hline Disconnector, damage with s.c. & 0,01 & 11 & 8 \\
\hline Separator, damage with s.c. & 0,01 & 3,5 & 10 \\
\hline Short-circuit-maker, damage with s.c. & 0,01 & 6 & 6 \\
\hline Gas-insulated switch 110 kV, damage with s.c. & 0,2 & 30 & 25 \\
\hline Power line 35-220 kV & 0,81 & 8,4 & 12 \\
\hline
\end{tabular}

Note: $\lambda$ - intensity of equipment failures; $T_{r}$ - restoring time; $t_{\mathrm{pl}}$ - delivery break time because of scheduled repairs.

Table 2. Indexes of reliability of traction substations (Fig. 2)

\begin{tabular}{|c|c|c|c|c|}
\hline $\begin{array}{c}\text { Scheme } \\
\text { by the Fig. 2 }\end{array}$ & $\lambda_{\Sigma}$ & $a$, 1/year & $T_{\text {t.av, } \text {, hours }}$ & $q_{a b}$ \\
\hline$a$ & 0,8340 & 0,1325 & 1,21 & $0,18 \cdot 10^{-4}$ \\
\hline$b$ & 0,2125 & 0,0229 & 5,32 & $0,14 \cdot 10^{-4}$ \\
\hline
\end{tabular}

The TS failure will be considered as the complete short and long periods of lost power. The reservation is carried out in case of refusal only one line of $110 \mathrm{kV}$. It means that the system will pass to a delivery from other line (reserved) in the absence of tension on a base line of a delivery, in the automatic mode.

For the scheme in Fig. $2 b$ we will consider calculations of entropy indicators in more details (index $Q$ from $H_{Q}(E)$ and other indexes we will lower for record reduction).

From Table 2 for the scheme (Fig. $2 b$ ) of $a=0.0229$, then by definition

$$
\begin{aligned}
& H\left(E_{a}\right)=\eta\left(e^{-a}\right)+\eta\left(1-e^{-a}\right)=\eta(0,9774)+\eta(0,0226)=0,156, \\
& H(D)=\sum_{i=1}^{5} H(D i)=\sum_{i=1}^{5}\left[\eta\left(e^{-\lambda_{i} t_{p}}\right)+\left[\eta\left(1-e^{-\lambda_{i} t_{p}}\right)\right]=\left[\eta\left(e^{-0,81}\right)+\left[\eta\left(1-e^{-0,81}\right)\right]+\right.\right. \\
& +\left[\eta\left(e^{-0,014}\right)+\left[\eta\left(1-e^{-0,014}\right)\right]+\left[\eta\left(e^{-0,01}\right)+\left[\eta\left(1-e^{-0,01}\right)\right]+\right.\right. \\
& +\left[\eta\left(e^{-0,2}\right)+\left[\eta\left(1-e^{-0,2}\right)\right]=1,8602 ;\right.
\end{aligned}
$$

The entropy of actions of relay protection of a source

$$
H(R)=\eta\left(Q_{s d}\right)+\eta\left(1-Q_{s d}\right),
$$

где $Q_{s d}$ - the probability of a source shutdown

$$
Q_{s d}=\sum_{i=n}^{k} q_{i},
$$

where $q_{i}-$ the probability of finding element in a repair state during the year.

$$
\begin{aligned}
& Q_{s d}=0,0041 . \\
& H(R)=\eta(0,0041)+\eta(1-0,0041)=0,038 .
\end{aligned}
$$


Table 3. Indexes schemes' reliability

\begin{tabular}{|c|c|c|c|}
\hline $\begin{array}{c}\text { Scheme according } \\
\text { to Fig. 2 }\end{array}$ & $H\left(E_{a}\right)$ & $H(D)$ & $H(R)$ \\
\hline$a$ & 0,541 & 1,338 & 0,0398 \\
\hline$b$ & 0,156 & 1,8602 & 0,038 \\
\hline
\end{tabular}

Entropy indicators were defined by using this technique. Results of similar calculations of these two schemes on the Fig. 2a are presented in Table 3.

\section{Conclusions}

It is possible to draw the following conclusions analyzing the results given in Table 3:

1. The scheme in Fig. $2 b$ is the best by entropy estimates in terms of fail-safety. Entropy indicators are more sensing and allow to judge a condition of the traction power supply system, and its structural reliability.

2. It is possible to estimate a share of presence of an entropy of a disabled state in total amount of the obtained information inherent in all structure of a system of traction power supply, comparing indicators. Such indicators are very useful as criterion at problem solving of reconstruction and modernization of traction substations. Thus, the entropy can be used as the size characterizing the level of structural reliability of a system of traction power supply.

\section{References}

1. Бройтман Э.3. Железнодорожные станциии и узльл. M., 2004, 365 с. [Broitman E.Z. The Railway station and the nodes. Moscow, 2004, 365 p. (in Russian)]

2. Хинчин А.Я. Понятие энтропии и теория информации. УМН, 1953, 8, 3 (55), 3 - 20. [Hinchin A.I. the concept of entropy and information theory. $U M N, 1953,8,3$ (55), 3-20. (in Russian)]

3. Дулесов А.С., Дулесова Н.В., Карандеев Д.Ю. Показатель разграничения уровня надежности технической системы по качественному признаку: энтропийный подход, Фундаментальные науки № 2, 2016, 477-481. [Dulesov A.S., Dulesova N.V., Karandeev D.Y. Delimitation indicator of level of reliability of technical system on the qualitative: character entropy approach, Fundamental Sciences No. 2, 2016, 477-481. (in Russian)]

4. Гук Ю.Б. Основы надежности электроэнергетических установок. Л.: Изд-во Ленингр. ун-та, 1976, 192 c. [Guk Y.B. Fundamentals of reliability of electric power plants. Publishing house St Petersburg University, 1976, 192 p. (in Russian)]

5. Эшби У.P. Введение в кибернетику. М. 1959, 432 c. [Ashby W.R. An Introduction to Cybernetics. Moscow, 1959, 432 p. (in Russian)]

6. Белов В.Г., Тремясов В.А. Энтропийные критерии надежности системы тягового электроснабжения. Борисовские чтения. Сборник материалов Всероссийской научнотехнической конференции 17-19 октября 2017. 120-122 c. [Belov V.G., Tremyasov V.A. Entropy criteria of reliability of electric traction system. Borisov readings. Collection of materials of the allRussian scientific and technical conference 17-19 October 2017. 120-122 p. (in Russian)] 
7. Назарычев А.Н., АндреевД.А., Сулыненков И.Н. Реконструкция открытых распределительных устройств подстанций 110 кВ на основе применения вакуумных выключателей и компактных блочно-модульных конструкций, Вестник ИГЭУ, 2011, 2, 1-7. [Nazarychev A.N., Andreev D.A., Soulimenkov I.N. The reconstruction of open distribution device $110 \mathrm{kV}$ substations, through the application of vacuum circuit breakers and compact modular designs, Vestnik IGEU, 2011, 2, 1-7. (in Russian)]

8. Нормы технологического проектирования подстанщий переменного тока с высшим напряжением 35-750 кB. М., 2009, 83 с. [Norms of technological designing of substations of alternating current with higher voltage 35-750 kV. Moscow, 2009, 83 p. (in Russian)]

9. Свод правил 224.1326000.2014 Тяговое электроснабжение железной дороги. М., 2014, 80 c. [A set of rules 224.1326000.2014 Traction power to the Railways. Moscow, 2014, 80 p. (in Russian)]

10. Прангишвили И.В. Энтропийные и другие системные закономерности: Вопросы управления сложными системами. Ин-т проблем управления им. В.А. Трапезникова. М.: Наука, 2003, 428 c. [Prangishvili I.V. Entropy and other systemic patterns: Issues of management of complex systems. In-t problems of its management. V.A. Trapeznikov. Moscow: Science, 2003, 428 p. (in Russian)] 